\title{
The Effects of Parenteral K1 Administration in Pseudoxanthoma Elasticum Patients Versus Controls. A Pilot Study
}

\begin{abstract}
Juan Luis Carrillo-Linares', María Inmaculada García-Fernández², María José Morillo, Purificación Sánchez ${ }^{4}$, José Rioja ${ }^{4}$, Francisco Javier Barón ${ }^{5}$, María José Ariza $^{4}$, Dominic J. Harrington ${ }^{6}$, David Card ${ }^{6}$, Federica Boraldi ${ }^{7}$, Daniela Quaglino ${ }^{7}$ and Pedro Valdivielso ${ }^{1,4 *}$

'Internal Medicine, Hospital Clínico Universitario Virgen de la Victoria, Málaga, Spain, ${ }^{2}$ Department of Human Physiology, University of Malaga, Málaga, Spain, ${ }^{3}$ Ophtalmology, Hospital Clínico Universitario Virgen de la Victoria, Málaga, Spain, ${ }^{4}$ Department of Medicine and Dermatology and Instituto de Biomedicina (IBIMA), University of Malaga, Málaga, Spain, ${ }^{5}$ Department of Preventive Medicine, Public Health and Science History, University of Málaga, Málaga, Spain, ${ }^{6}$ The Nutristasis Unit, Viapath, King's Healthcare Partners, St. Thomas' Hospital, London, United Kingdom, ' Department of Life Sciences, University of Modena and Reggio Emilia, Modena, Italy
\end{abstract}

OPEN ACCESS

Edited by:

Alexander A. Navarini, Universität Zürich, Switzerland

Reviewed by: Luis Puig,

Universidad Autónoma de Barcelona, Spain

Franz Trautinger, Universitätsklinikum St. Pölten, Austria

*Correspondence: Pedro Valdivielso valdivielso@uma.es

Specialty section: This article was submitted to Dermatology,

a section of the journal

Frontiers in Medicine

Received: 28 August 2017 Accepted: 20 March 2018 Published: 16 April 2018

Citation:

Carrillo-Linares $\mathrm{JL}$, García-Fernández MI, Morillo MJ, Sánchez P, Rioja J, Barón FJ, Ariza MJ, Harrington DJ, Card D,

Boraldi F, Quaglino $D$ and Valdivielso P (2018) The Effects of

Parenteral K1 Administration in Pseudoxanthoma Elasticum Patients Versus Controls. A Pillot Study. Front. Med. 5:86. doi: 10.3389/fmed.2018.00086
Introduction: Pseudoxanthoma elasticum (PXE) is a rare disease caused by mutations in the ABCC6 gene. Vitamin $\mathrm{K} 1$ is involved in the posttranslational carboxylation of some proteins related to inhibition of the calcification process. Our aim was to investigate, in patients affected by PXE, baseline levels of vitamin $\mathrm{K}_{1}$-dependent proteins and -metabolites and whether parenteral administration of phytomenadione was effective in modulating their levels.

Methods: We included eight PXE patients with typical clinical symptoms (skin, retina, and vascular calcification) and two ABCC6 causative mutations; 13 clinically unaffected first-degree patients' relatives (9 carrying one ABCC6 mutation and 4 non-carriers). We assessed urinary vitamin K1 metabolites and serum Glu- and Gla-OC, Gas6 and undercaboxylated prothrombin (PIVKA-II), at baseline and after 1 and 6 weeks after a single intramuscular injection of $10 \mathrm{mg}$ vitamin $\mathrm{K} 1$.

Results: Comparison of PXE patients, heterozygous, and non-carriers revealed differences in baseline levels of serum MK-4 and of urinary vitamin K metabolites. The response to phytomenadione administration on vitamin $\mathrm{K}$-dependent proteins was similar in all groups.

Conclusion: The physiological axis between vitamin $\mathrm{K}_{1}$ and vitamin $\mathrm{K}$-dependent proteins is preserved; however, differences in the concentration of vitamin $\mathrm{K}$ metabolites and of MK-4 suggest that vitamin K1 metabolism/catabolism could be altered in PXE patients.

Keywords: vitamin K, pseudoxanthoma elasticum, carboxylated proteins, osteocalcin, menaquinone

\section{INTRODUCTION}

Pseudoxanthoma elasticum (PXE) is a rare disease caused by mutations in the $A B C C 6$ gene encoding for the multidrug resistance-associated protein 6 (MRP6) highly expressed in the liver (1). The disease is characterized by progressive calcification of elastic fibers that undergo fragmentation and deformation with loss of function. Retinal damage at Bruch's membrane causing central blindness, 
skin papules, and folds as well as vascular calcification responsible for ischemia are the most frequent clinical features (2).

The disease pathogenesis has not yet completely understood, though several hypotheses have been postulated. A series of in vitro and in vivo studies suggested that absent or nonfunctional MRP6 can influence the availability of circulating factors from the liver, which are physiologically required to prevent aberrant calcification and which are able to modulate the phenotype of mesenchymal cells, such as fibroblasts (3). As a consequence of fibroblasts' abnormal protein profile (4), extracellular matrix components are differentially synthesized and/or degraded thus altering connective tissue homeostasis (4-6). Within this context, progressive mineralization of elastic fibers is probably sustained by an altered balance between factors inducing and inhibiting the mineralization process, such as fetuin A, Matrix Gla Protein (MGP), alkaline phosphatase, and pyrophosphate (7-11).

The association of vitamin $\mathrm{K}$ deficiency with ectopic calcification and with PXE-like phenotype $(12,13)$ has recently drawn attention to a number of proteins involved in ectopic calcification. Some of these proteins, such as MGP, osteocalcin (OC) and growth arrest-specific protein 6 (Gas6), require posttranslational vitamin $\mathrm{K}$-dependent carboxylation to be fully active. The carboxylase enzyme uses the oxygenation of vitamin $\mathrm{K}$ hydroquinone to subtract a hydrogen from glutamyl residues $(\mathrm{Glu})$ and to generate a carbanion that, incorporating $\mathrm{CO}_{2}$ by nucleophilic attack, produces a carboxylated-Glu known as Gla (14).

The observations that: (i) MGP levels were decreased in the serum of PXE patients compared to non-carriers (15), (ii) the concentration of MGP in the serum of $\mathrm{Abcc6}^{-/-}$mice was similarly reduced when compared to wild-type animals and (iii) most of the MGP isolated from the liver of $\mathrm{Abcc6}^{-/-}$ mice was largely under-carboxylated, thus exhibiting reduced or no activity (16), suggested a possible pathogenic role of vitamin $\mathrm{K}$ in PXE (17). Consistently, serum vitamin $\mathrm{K}$ concentrations in PXE patients appeared significantly decreased compared to control subjects (18). Despite these findings, treatment of $\mathrm{Abcc6}^{-1-}$ mice with different forms of vitamin $\mathrm{K}$ failed to counteract the calcification process (19-21). In addition, in vitro experiments on fibroblasts isolated from controls and PXE patients demonstrated that these cells had a similar dose-dependent uptake of both vitamin $K_{1}$ and $K_{2}$ and had a significant increase of total protein carboxylation. By contrast, Gla-MGP was significantly lower in PXE fibroblasts (9), indicating that, in these patients, MGP cannot be efficiently carboxylated by fibroblasts, even in the presence of an adequate amount of the vitamin.

It remains questionable whether vitamin $\mathrm{K}$ metabolism is altered in PXE patients, since type and dosage of vitamin $\mathrm{K}$ have different effects depending on the model being studied $(22,23)$.

Therefore, we measured, for the first time in PXE patients and in unaffected subjects (i.e., heterozygous ABCC6 mutation carriers and non-carriers), baseline levels of vitamin $\mathrm{K}$-dependent proteins and -metabolites and their changes after parenteral administration of a single dose of phytomenadione (vitamin $\mathrm{K}_{1}$ ).

\section{PATIENTS AND METHODS}

Pseudoxanthoma elasticum patients and unaffected individuals (patients' first-degree relatives) were recruited through the Spanish Association of PXE Patients. Inclusion criteria for patients were: typical clinical features (i.e., skin and ocular involvement), skin biopsy positive to the von Kossa staining, presence of two ABCC6 causative mutations, either homozygous or compound heterozygous (24). Inclusion criteria for carriers were: complete absence of PXE clinical symptoms and one ABCC6 mutation. Inclusion criteria for non-carriers were: absence of PXE clinical manifestations and no ABCC6 mutations. In all cases, exclusion criteria were: negative informed consent, lack of molecular diagnosis, vegetarian diet, use of warfarin, intention to become pregnant during the study, age $<18$ years and hypersensitivity to vitamin K. Finally, eight PXE patients, nine heterozygous carriers, and four non-carriers were included in the study. All enrolled subjects were advised to keep to their usual diet for the duration of the study.

All participants in the study signed informed consent and the research was approved by the Ethical Review and Investigative Board of Hospital Universitario Virgen de la Victoria, Málaga, Spain.

Genetic analyses were carried out as previously described $(25,26)$.

EDTA, citrated and heparinized plasma, serum and urine samples were obtained at baseline and at 1 and 6 weeks after a single intramuscular injection in the buttock of $10 \mathrm{mg}$ phytomenadione in $1 \mathrm{ml}$ (Konakion@, Roche Pahrma, Madrid). Because subjects had similar body-mass index (Table 1), the same dose of $10 \mathrm{mg}$ of phytomenadione was used for all subjects. Samples' collection time points were selected in order to determine whether treatment has an effect on vitamin K-dependent proteins and if these effects are lasting. Effects of treatment may in fact be prolonged since vitamin $\mathrm{K}$ is extensively recycled

TABLE 1 | Baseline characteristics of pseudoxanthoma elasticum (PXE) patients, ABCC6 mutation carriers, and non-carriers.

\begin{tabular}{|c|c|c|c|}
\hline & $\begin{array}{l}\text { PXE patients } \\
\quad(n=8)\end{array}$ & $\begin{array}{c}\text { ABCC6 carriers } \\
(n=9)\end{array}$ & $\begin{array}{c}\text { Non-carriers } \\
(n=4)\end{array}$ \\
\hline Age (years) & $39 \pm 13$ & $48 \pm 17$ & $57 \pm 5$ \\
\hline Sex (women) & $6(75 \%)$ & $5(55 \%)$ & $1(25 \%)$ \\
\hline Weight (kg) & $72 \pm 11$ & $65 \pm 10$ & $74 \pm 4$ \\
\hline BMI $\left(\mathrm{kg} / \mathrm{m}^{2}\right)$ & $29 \pm 5.1$ & $25 \pm 3$ & $28 \pm 4$ \\
\hline \multicolumn{4}{|l|}{ Smoking } \\
\hline Current & $2(25 \%)$ & $4(44 \%)$ & $1(25 \%)$ \\
\hline Past & $1(12 \%)$ & & \\
\hline Alcohol & $1(12 \%)$ & $2(22 \%)$ & $1(25 \%)$ \\
\hline Dyslipidaemia & $2(25 \%)$ & $3(33 \%)$ & $1(25 \%)$ \\
\hline $\begin{array}{l}\text { Systolic blood } \\
\text { pressure (mmHg) }\end{array}$ & $117 \pm 12$ & $110 \pm 20$ & $133 \pm 10$ \\
\hline $\begin{array}{l}\text { Diastolic blood } \\
\text { pressure }(\mathrm{mmHg})\end{array}$ & $71 \pm 18$ & $68 \pm 14$ & $87 \pm 8$ \\
\hline Ankle-brachial index & $1.12 \pm 0.2$ & $1.14 \pm 0.08$ & $1.25 \pm 0.1$ \\
\hline$<0.9$ & $1(12 \%)$ & 0 & 0 \\
\hline$>1.4$ & 2 (25\%) & $1(10 \%)$ & $1(25 \%)$ \\
\hline
\end{tabular}

Data are shown as mean $\pm S D$ or number (percentage). 
prior to elimination, and supplementation is actually provided to individuals with normal nutritional intake and in the absence of any clinically relevant deficit of the vitamin (27).

Serum menaquinone-4 (MK-4) was measured by reversedphase HPLC with fluorimetric detection (Waters 515). Chromatography was performed in isocratic conditions using an end-capped C18 column. Sample preparation was developed according to the protocol previously described (28).

Commercial ELISA kits were used to measure des- $\boldsymbol{\gamma}$-carboxy prothrombin (DCP) (Prothrombin Induced by Vitamin K Absence or Antagonist II-PIVKA-II) in citrated plasma (Asserachrom, Diagnostica Stago, Asnière-sur-Seine, France), Fetuin A in EDTA-plasma (Quantikine, R\&D System Inc., Abingdon, UK), Gas6 in serum (USCN, Life Science Inc., Houston, TX, USA), under-carboxylated (Glu) OC (EIA, Glu-Oc) in serum (Takara Bio Inc., Shiga, Japan), carboxylated (Gla) OC (EIA, Gla-OC) in heparinized plasma (Takara Bio Inc., Shiga, Japan).

Urinary 2-methyl-3-(5'-carboxy-3'-methyl-2' -pentenyl)1,4-naphthoquinone (7C-aglycone) and 2-methyl-3-(3'-3'carboxymethylpropyl)-1,4-naphthoquinone (5C-aglycone) metabolite derivatives of vitamin $\mathrm{K}$ were measured at each time point by HPLC with electromechanical detection, as previously described $(29,30)$. Urinary vitamin $\mathrm{K}$ metabolite concentrations were corrected for urinary creatinine concentration.

Statistical analyses were performed using "R: A Language and Environment for Statistical Computing." Comparison between groups was performed using a linear mixed-model with PXE as fixed effect, adjusted by age and gender and the individual as a random effect along the repeated measurements.

\section{RESULTS}

Age, gender, and relevant clinical data are detailed for PXE patients, heterozygous carriers and non-carriers (Table 1). Standard laboratory parameters (hematology, coagulation parameters, glucose and lipid status, mineral and electrolytes, liver, kidney, and thyroid function) were similar in all subjects and vitamin $\mathrm{K}_{1}$ treatment did not significantly affect any of these parameters (data not shown).

Clinical manifestations of PXE involving skin, eyes, the vascular system, and other organs were described and quantified according to the Phenodex Score system (31). PXE patients with typical clinical manifestations always gave a total score $\geq 3$ (Table 2). As expected, to all heterozygous carriers was attributed a 0 score since dermal, ocular, vascular, gastrointestinal, and cardiac symptoms were not observed (Table 3).

Table 4 show that MK-4 was higher in PXE patients at baseline compared to heterozygous and non-carriers. At 1 week post-vitamin $\mathrm{K}_{1}$ administration, MK-4 increased in all groups. Similar values were also observed at 6 weeks. Statistical analyses over repeated measurements indicate that, despite the similar behavior observed after treatment, differences between groups were maintained over the six week-period of the study $(p<0.05)$.

The concentrations of the $5 \mathrm{C}$ - and $7 \mathrm{C}$-aglycone vitamin $\mathrm{K}$ metabolites were measured at baseline and after treatment, since their levels reflect total vitamin $\mathrm{K}$ status. Urinary volume excretion did not reveal significant differences between subjects (data not shown). As shown in Table 4, vitamin $\mathrm{K}_{1}$ was largely metabolized to terminal 5C-aglycone in all groups. Interestingly, 5C-aglycone levels in PXE patients and ABCC6 mutation carriers were significantly lower than those in non-carriers $(p<0.05)$. A similar trend was observed also as far as $7 \mathrm{C}$-aglycone. To be noted that differences between groups were evident already at baseline. Figure 1 (lower panels) shows the percentage of 5C- or $7 \mathrm{C}$-aglycone on total aglycones $(5 \mathrm{C}+7 \mathrm{C})$ measured in noncarriers, ABCC6 carriers and PXE patients. These values allow to compare, within each group, how vitamin $\mathrm{K}_{1}$ was metabolized with time. In particular, in both non-carries and ABCC6 carriers, 7C-aglycone levels progressively increased over time, whereas an opposite trend was observed in PXE patients.

TABLE 2 | Clinical and molecular features in pseudoxanthoma elasticum (PXE) patients.

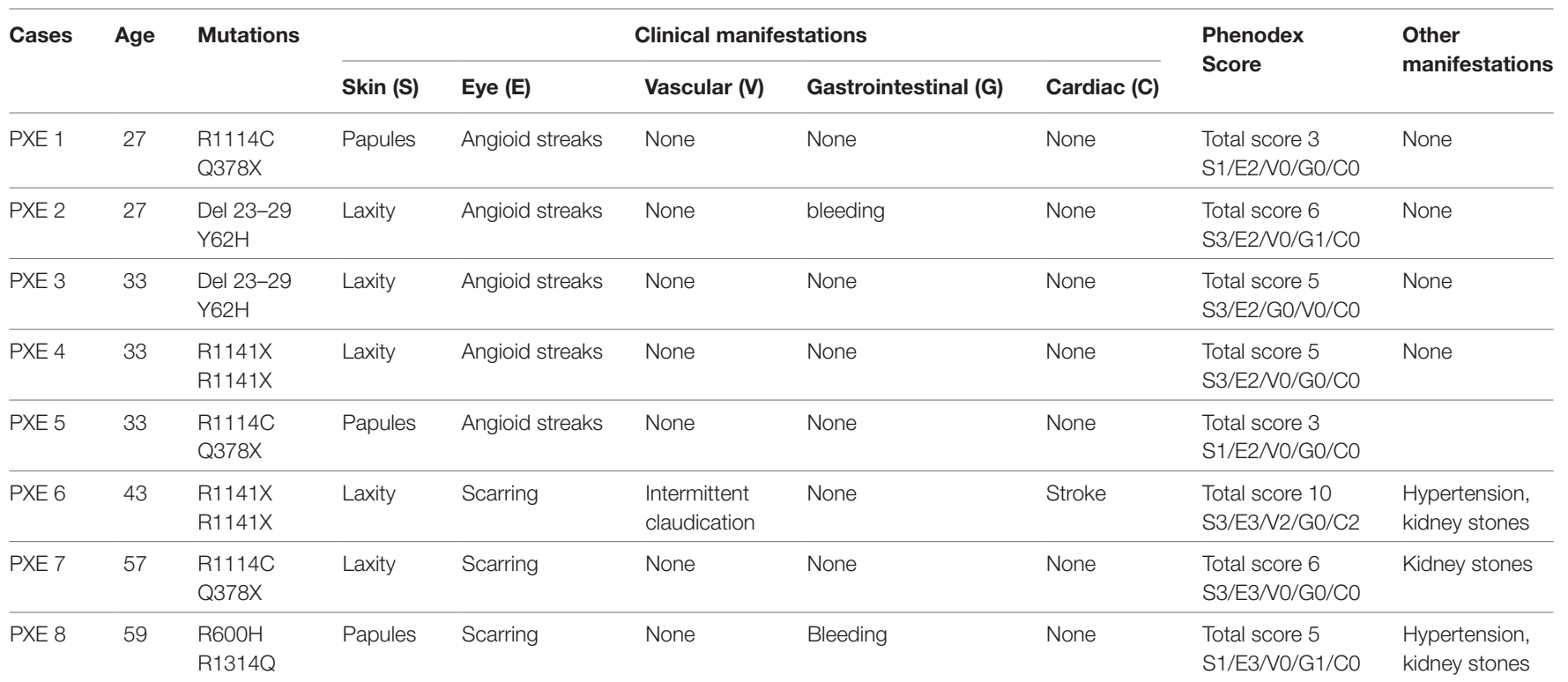


TABLE 3 | Clinical and molecular features in ABCC6 mutation carriers.

\begin{tabular}{|c|c|c|c|c|c|c|c|c|c|}
\hline \multirow[t]{2}{*}{ Cases } & \multirow[t]{2}{*}{ Age } & \multirow[t]{2}{*}{ Mutations } & \multicolumn{5}{|c|}{ Clinical manifestations } & \multirow[t]{2}{*}{ Phenodex Score } & \multirow{2}{*}{$\begin{array}{l}\text { Other } \\
\text { manifestations }\end{array}$} \\
\hline & & & Skin (S) & Eye (E) & Vascular (V) & Gastrointestinal (G) & Cardiac (C) & & \\
\hline C 1 & 23 & $\begin{array}{l}\mathrm{R} 1314 \mathrm{Q} \\
-\end{array}$ & None & None & None & None & None & Total Score 0 SO/EO/NO/GO/CO & None \\
\hline C 2 & 25 & $\begin{array}{l}\mathrm{R} 1141 \mathrm{X} \\
-\end{array}$ & None & None & None & None & None & Total Score 0 SO/EO/NO/GO/CO & None \\
\hline C 3 & 34 & $\begin{array}{l}\mathrm{R} 1141 \mathrm{X} \\
-\end{array}$ & None & None & None & None & None & Total Score O SO/EO/NO/GO/CO & $\begin{array}{l}\text { Hypertension, } \\
\text { kidney stones }\end{array}$ \\
\hline C 4 & 51 & $\begin{array}{l}\mathrm{R} 600 \mathrm{H} \\
-\end{array}$ & None & None & None & None & None & Total Score O SO/EO/NO/GO/CO & None \\
\hline C 5 & 52 & $\begin{array}{l}\mathrm{R} 807 \mathrm{Q} \\
-\end{array}$ & None & None & None & None & None & Total Score 0 SO/EO/VO/GO/CO & Kidney stones \\
\hline C 6 & 63 & $\begin{array}{l}\mathrm{R} 600 \mathrm{H} \\
-\end{array}$ & None & None & None & None & None & Total Score 0 SO/EO/VO/GO/CO & None \\
\hline C 7 & 65 & $\begin{array}{l}\mathrm{R} 1141 \mathrm{X} \\
-\end{array}$ & None & None & None & None & None & Total Score 0 SO/EO/NO/GO/CO & None \\
\hline C 8 & 67 & $\begin{array}{l}\mathrm{R} 1141 \mathrm{X} \\
-\end{array}$ & None & None & None & None & None & Total Score O SO/EO/NO/GO/CO & Kidney stones \\
\hline C 9 & 68 & $\begin{array}{l}\mathrm{R} 1141 \mathrm{X} \\
-\end{array}$ & None & None & None & None & None & Total Score o so/EO/NO/GO/CO & Atrial fibrillation \\
\hline
\end{tabular}

In order to investigate the effects of vitamin $\mathrm{K}_{1}$ supplementation, several vitamin K-dependent proteins were measured. Table 4 shows that PIVKA-II concentration were similar in PXE patients, in non-carriers and in ABCC6 carriers, at both baseline and post-vitamin $\mathrm{K}$ administration.

Serum Gas6 protein was similarly expressed at baseline in all groups (Table 4). Vitamin $\mathrm{K}_{1}$ administration diminished Gas6 concentration in all groups. Statistical analyses over repeated measurements revealed significant differences after treatment compared to baseline.

Figure 2 shows the effect of phytomenadione supplementation on the carboxylation status of OC, an extra-hepatic vitamin K-dependent protein involved in the calcification process. At baseline, both under-carboxylated (Glu)- and carboxylated (Gla)-OC were similar in all groups (data not shown). At 1 week post-treatment, the ratio between Glu- and Gla-OC was significantly reduced in all groups $(p<0.001)$. At 6 weeks after treatment, values returned to baseline concentrations (Figure 2).

Finally, as shown in Table 4, fetuin A levels, as expected for a non-vitamin K-dependent protein, did not change significantly over time.

\section{DISCUSSION}

It is well known that vitamin $\mathrm{K}$ has a role in the occurrence of ectopic calcification (32). Although suboptimal vitamin $\mathrm{K}$ status has been observed in PXE patients, thus suggesting that this vitamin could exert a key role in the defective carboxylation of $\operatorname{MGP}(8,15,16,18)$; however, other experimental evidence does not support this hypothesis $[10,19,21]$. Nevertheless, it remains uncertain whether vitamin $\mathrm{K}$ metabolism/catabolism is altered in PXE patients.
The increased serum MK-4 concentration detected after phytomenadione administration indicates that the conversion of vitamin $\mathrm{K}_{1}$ to $\mathrm{MK}-4$ is preserved in PXE, confirming previous in vitro data (9). However, differences at baseline and after treatment between patients and unaffected individuals may suggest possible altered regulation of metabolite production and/or in excretion pathways.

The significance of urinary aglycones measurements, as biomarkers of vitamin $\mathrm{K}$ status, resides in the observation that these metabolites reflect the excretion of total vitamins $\mathrm{K}$, including MK-4 formed by conversion of vitamin $K_{1}$ (29). In all subjects the excretion of the $5 \mathrm{C}$-aglycone was greater than that of 7C-aglicone. However, at baseline, PXE patients exhibited reduced excretion of the urinary $5 \mathrm{C}$-aglycone, indicating a suboptimal vitamin $\mathrm{K}$ status (18). Moreover, after vitamin $\mathrm{K}_{1}$ supplementation, non-carriers and ABCC6 carriers showed an increase of urinary $7 \mathrm{C}$-aglycone excretion, whereas an opposite trend was present in PXE patients. Although the significance of these data could be explored also in the light of biliary excretion pathways (29), data suggest that vitamin $\mathrm{K}$ metabolism is modified in PXE.

To further investigate the effects of parenteral vitamin $K_{1}$ supplementation, we measured the abundance of DCP, also known as prothrombin induced by vitamin $\mathrm{K}$ absence (PIVKA-II), an abnormal prothrombin molecule with diminished coagulation activity as a consequence of incomplete hepatic vitamin K-dependent carboxylation $(33,34)$. In this study, DCP levels, as well as coagulation test parameters, were similar in PXE patients and in heterozygous carriers and in non-carriers, confirming that vitamin K-dependent coagulation factors are not affected in PXE. By contrast, PXE-like manifestations due to mutations in the gamma-glutamyl carboxylase gene are associated to altered carboxylation of coagulations factors (18). 
TABLE 4 | Vitamin K metabolites and dependent proteins at baseline and at 1 and 6 weeks post-phytomenadione administration in pseudoxanthoma elasticum (PXE) patients, in non-carriers and in ABCC6 carriers.

\begin{tabular}{|c|c|c|c|c|}
\hline Group & Baseline & Week 1 & Week 6 & Significance (along time) \\
\hline \multicolumn{5}{|l|}{ Vitamin K metabolites } \\
\hline \multicolumn{5}{|l|}{ Serum MK-4 (ng/mL) } \\
\hline Non-carriers & $15.5 \pm 5.2$ & $25.4 \pm 12.4$ & $23.7 \pm 32.0$ & ns \\
\hline ABCC6 carriers & $20.0 \pm 14.0$ & $27.1 \pm 12.4$ & $23.1 \pm 6.9$ & ns \\
\hline PXE & $28.8 \pm 26.9$ & $38.3 \pm 32.0$ & $41.6 \pm 17.8$ & ns \\
\hline Significance (among groups) & $\star \S$ & $\star \S$ & $\star \S$ & \\
\hline \multicolumn{5}{|l|}{ Serum MK-7 (ng/mL) } \\
\hline Non-carriers & $25.1 \pm 8.8$ & $22.8 \pm 16.9$ & $18.4 \pm 7.8$ & ns \\
\hline ABCC6 carriers & $14.8 \pm 11.3$ & $23.4 \pm 8.7$ & $22.3 \pm 8.0$ & ns \\
\hline PXE & $12.2 \pm 8.7$ & $23.0 \pm 9.0$ & $22.3 \pm 2.0$ & ns \\
\hline Significance (among groups) & ns & ns & ns & \\
\hline \multicolumn{5}{|c|}{ Urinary $5 \mathrm{C}$-vitamin $\mathrm{K}$ metabolite $(\mathrm{mg} / \mathrm{g})$} \\
\hline Non-carriers & $6.86 \pm 2.71$ & $7.34 \pm 2.82$ & $4.21 \pm 1.88$ & ns \\
\hline ABCC6 carriers & $3.87 \pm 3.32$ & $4.53 \pm 3.53$ & $3.15 \pm 3.12$ & ns \\
\hline PXE & $3.27 \pm 2.61$ & $4.23 \pm 4.35$ & $3.63 \pm 2.25$ & ns \\
\hline Significance (among groups) & * & * & ns & \\
\hline \multicolumn{5}{|c|}{ Urinary 7C-vitamin K metabolite (mg/g) } \\
\hline Non-carriers & $3.41 \pm 1.48$ & $3.98 \pm 1.56$ & $2.65 \pm 1.22$ & ns \\
\hline ABCC6 carriers & $1.54 \pm 1.16$ & $2.55 \pm 1.89$ & $1.64 \pm 0.90$ & ns \\
\hline PXE & $2.21 \pm 1.33$ & $2.49 \pm 1.59$ & $1.96 \pm 1.28$ & ns \\
\hline Significance (among groups) & ns & ns & ns & \\
\hline \multicolumn{5}{|c|}{ Total urinary vitamin $\mathrm{K}$ metabolites $(\mathrm{mg} / \mathrm{g})$} \\
\hline Non-carriers & $10.2 \pm 4.19$ & $11.3 \pm 4.06$ & $6.86 \pm 2.89$ & ns \\
\hline ABCC6 carriers & $5.40 \pm 4.45$ & $7.07 \pm 5.27$ & $4.79 \pm 3.80$ & ns \\
\hline PXE & $5.48 \pm 3.71$ & $6.72 \pm 5.71$ & $5.59 \pm 3.26$ & ns \\
\hline Significance (among groups) & ns & ns & ns & \\
\hline \multicolumn{5}{|c|}{ Vitamin K-dependent proteins } \\
\hline \multicolumn{5}{|l|}{ Serum GAS6 (ng/mL) } \\
\hline Non-carriers & $58.7 \pm 7.61$ & $52.8 \pm 18.7$ & $41.2 \pm 5.4$ & $p<0.05$ \\
\hline ABCC6 carriers & $51.9 \pm 9.18$ & $46.3 \pm 7.1$ & $40.6 \pm 7.4$ & $p<0.05$ \\
\hline PXE & $47.3 \pm 9.14$ & $47.9 \pm 11.4$ & $38.9 \pm 8.6$ & $p<0.05$ \\
\hline Significance (among groups) & ns & $\mathrm{ns}$ & ns & \\
\hline \multicolumn{5}{|c|}{ Serum Glu-Osteocalcin (ng/mL) } \\
\hline Non-carriers & $7.0 \pm 1.5$ & $3.1 \pm 1.5$ & $5.9 \pm 2.2$ & $p<0.05$ \\
\hline ABCC6 carriers & $14.6 \pm 8.8$ & $11.5 \pm 8.9$ & $13.9 \pm 8.8$ & $p<0.05$ \\
\hline PXE & $11.7 \pm 5.4$ & $7.2 \pm 2.6$ & $10.1 \pm 4.9$ & $p<0.05$ \\
\hline Significance (among groups) & $\mathrm{ns}$ & ns & ns & \\
\hline \multicolumn{5}{|c|}{ Serum Gla-Osteocalcin (ng/mL) } \\
\hline Non-carriers & $12.4 \pm 5.5$ & $18.6 \pm 4.9$ & $13.0 \pm 6.0$ & $p<0.05$ \\
\hline ABCC6 carriers & $13.7 \pm 5.9$ & $20.2 \pm 8.9$ & $14.2 \pm 5.4$ & $p<0.05$ \\
\hline PXE & $12.6 \pm 8.3$ & $15.9 \pm 9.1$ & $14.3 \pm 9.6$ & $p<0.05$ \\
\hline Significance (among groups) & ns & ns & ns & \\
\hline \multicolumn{5}{|l|}{ PIVKA-II (ng/ml) } \\
\hline Non-carriers & $1.35 \pm 0.56$ & $1.13 \pm 0.48$ & $1.17 \pm 0.72$ & ns \\
\hline ABCC6 carriers & $1.56 \pm 0.58$ & $1.29 \pm 0.44$ & $1.33 \pm 0.41$ & ns \\
\hline PXE & $1.25 \pm 0.38$ & $1.13 \pm 0.44$ & $1.11 \pm 0.50$ & ns \\
\hline Significance (among groups) & ns & ns & ns & \\
\hline \multicolumn{5}{|l|}{ Serum Fetuin (ng/mL) } \\
\hline Non-carriers & $893 \pm 535$ & $843 \pm 498$ & $925 \pm 646$ & ns \\
\hline ABCC6 carriers & $959 \pm 453$ & $927 \pm 364$ & $813 \pm 325$ & ns \\
\hline PXE & $795 \pm 146$ & $787 \pm 227$ & $834 \pm 223$ & ns \\
\hline Significance (among groups) & ns & ns & ns & \\
\hline
\end{tabular}

${ }^{*} p<0.05$ ABCC6 carriers or PXE versus non-carriers. $s p<0.05$ ABCC 6 carriers versus $P X E$.

Data shown as mean $\pm S D$.

To evaluate the effects of phytomenadione administration on extra-hepatic tissues, we measured plasma levels of Gas6, a vitamin K-dependent protein that, differently to the homologous anticoagulant protein $S(35,36)$, is synthesized by fibroblasts, endothelium, vascular smooth muscle, and bone marrow cells
$(37,38)$, although its role in the calcification process still remains on a speculative basis (39). According to our results, plasma levels of this protein, at baseline, were similar in all groups and progressively decreased with time, without significant difference between patients and unaffected subjects. Since vitamin 

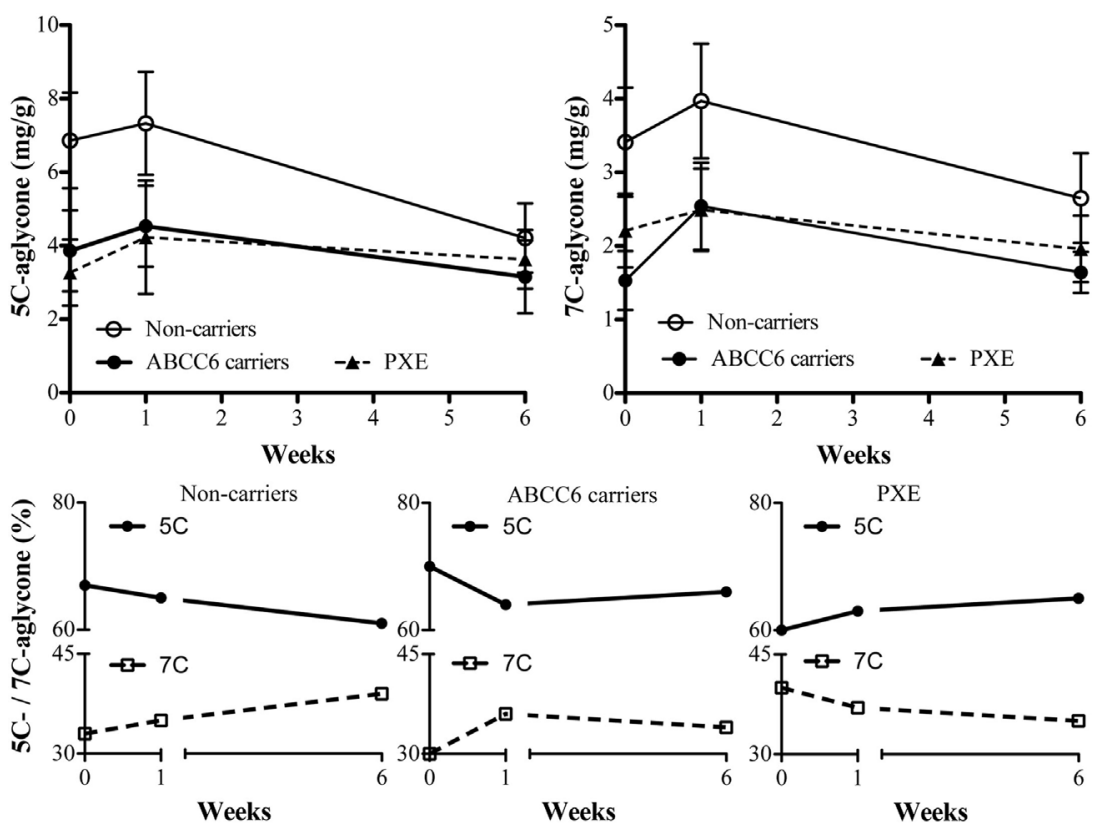

FIGURE 1 | 5C- and 7C-aglycone urinary vitamin K metabolites were measured by HPLC (mg/g creatinine) in pseudoxanthoma elasticum (PXE) patients, in heterozygous ABCC6 mutation carriers (ABCC6 carriers) and non-carriers at baseline (week 0) and after 1 and 6 weeks after parenteral phytomenadione administration. Data are expressed as mean values \pm SD in upper panels and as percentage of $5 \mathrm{C}$ - or $7 \mathrm{C}$-aglycone ratio on total aglycones in lower panels.

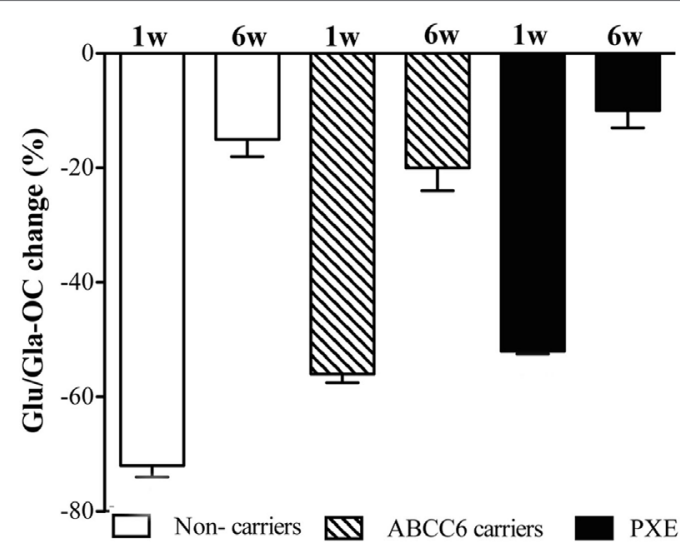

FIGURE 2 | Ratio of circulating Glu-osteocalcin (Glu-OC) and Gla-osteocalcin (Gla-OC) measured by ELISA in pseudoxanthoma elasticum (PXE) patients, in heterozygous ABCC6 mutation carriers (ABCC6 carriers) and in non-carriers after 1 and 6 weeks post-phytomenadione administration. Data are expressed as percentage reduction (means value $\pm \mathrm{SD}$ ) compared to baseline $(p<0.05$ along time for the three groups).

K-dependent carboxylation of Gas6 favors protein binding to the Axl tyrosine kinase receptors (40), it could be suggested that the decrease in Gas6 levels observed in this study could be related to increased binding and consequently to reduced availability of free Gas6 in serum, further supporting the concept that vitamin-K dependent carboxylation per se is not affected in PXE.

To further assess the effects of parental phytomenadione administration, we have evaluated the carboxylated (gla) and undercarboxylated (glu) forms of OC, a protein involved in the remodeling of calcified matrix (14). In agreement with previous data (18) baseline glu-OC and gla-OC levels were not modified in PXE compared to unaffected subjects. Moreover, results support the observation that PXE patients similarly to unaffected subjects respond to vitamin $\mathrm{K}$ administration (10) by increasing carboxylated-OC. Since, vitamin K is believed to prevent vasculopathy (41), the hypothesis that prolonged elevation of vitamin K-dependent Gla-OC may delay tissue calcification could be explored in future studies.

Finally, the observation that fetuin A, a non-vitamin $\mathrm{K}$-dependent $\alpha$-glycoprotein synthesized by hepatocytes, is not affected by treatment, is a clear demonstration that changes observed after phytomenadione administration are the result of the treatment and not of non-specific metabolic interactions, e.g., acute phase response.

It has to be taken into account that PXE is a rare disorder. A restriction of the present investigation is related to the low number of patients enrolled and the resulting limited statistical power. Nevertheless, results from this pilot study indicate that, in PXE, phytomenadione might be able to positively influence the g-carboxylation process, thus indicating a proof of concept that vitamin $\mathrm{K}$ may actually exert some beneficial effects on calcification-related proteins.

\section{CONCLUSION}

In conclusion and examining vitamin $\mathrm{K}$-dependent proteins and vitamin $\mathrm{K}$ metabolites, this pilot study indicates that PXE patients demonstrate altered vitamin $\mathrm{K}$ metabolism compared 
to heterozygotes and non-carriers. Despite this, the response to parenteral phytomenadione administration is similar in patients and in unaffected individuals, suggesting that the physiological axis between vitamin $\mathrm{K}$ and vitamin $\mathrm{K}$-dependent proteins is preserved in PXE. Because vitamin $\mathrm{K}$ is known to prevent vasculopathy (41), the elevation of Gla-OC seen in PXE patients after phytomenadione administration, may suggest that vitamin $\mathrm{K}$ treatment, if sustained over time, could contribute to delay tissue calcification.

\section{ETHICS STATEMENT}

The present study was approved by the Comité de Ética de la Investigación Clínica de Málaga. All participants signed the informed consent.

\section{AUTHOR CONTRIBUTIONS}

JC participated in the design of the study, carried out patient's data capture and helped to draft the manuscript. MG-F participated in the design and performed laboratory analyses.

\section{REFERENCES}

1. Matsuzaki Y, Nakano A, Jiang QJ, Pulkkinen L, Uitto J. Tissue-specific expression of the ABCC6 gene. J Invest Dermatol (2005) 125:900-5. doi:10.1111/j.0022-202X.2005.23897.x

2. Quaglino D, Boraldi F, Annovi G, Ronchetti I. The multifaceted complexity of genetic diseases: a lesson from pseudoxanthoma elasticum. In: Ikehara K, editor. Advances in the Study of Genetic Disorders. InTech (2012). p. 289-318.

3. Ronchetti I, Boraldi F, Annovi G, Cianciulli P, Quaglino D. Fibroblast involvement in soft connective tissue calcification. Front Genet (2013) 4:2. doi:10.3389/fgene.2013.00022

4. Boraldi F, Annovi G, Guerra D, Paolinelli Devincenzi C, Garcia-Fernandez MI, Panico F, et al. Fibroblast protein profile analysis highlights the role of oxidative stress and vitamin $\mathrm{K}$ recycling in the pathogenesis of pseudoxanthoma elasticum. Proteomics Clin Appl (2009) 3:1084-98. doi:10.1002/prca. 200900007

5. Boraldi F, Losi L, Quaglino D. Pigment epithelial-derived factor: a new player in the calcification of dermal elastic fibre? Br J Dermatol (2017) 177:e44-6. doi:10.1111/bjd.15223

6. Quaglino D, Sartor L, Garbisa S, Boraldi F, Croce A, Passi A, et al. Dermal fibroblasts from pseudoxanthoma elasticum patients have raised MMP-2 degradative potential. Biochim Biophys Acta (2005) 1741:42-7. doi:10.1016/j. bbadis.2004.09.012

7. Hendig D, Schulz V, Arndt M, Szliska C, Kleesiek K, Gotting C. Role of serum fetuin-A, a major inhibitor of systemic calcification, in pseudoxanthoma elasticum. Clin Chem (2006) 52:227-34. doi:10.1373/clinchem.2005.059253

8. Gheduzzi D, Boraldi F, Annovi G, DeVincenzi CP, Schurgers LJ, Vermeer C, et al. Matrix Gla protein is involved in elastic fiber calcification in the dermis of pseudoxanthoma elasticum patients. Lab Invest (2007) 87:998-1008. doi:10.1038/labinvest.3700667

9. Boraldi F, Annovi G, Vermeer C, Schurgers LJ, Trenti T, Tiozzo R, et al. Matrix gla protein and alkaline phosphatase are differently modulated in human dermal fibroblasts from PXE patients and controls. J Invest Dermatol (2013) 133:946-54. doi:10.1038/jid.2012.460

10. Boraldi F, Annovi G, Bartolomeo A, Quaglino D. Fibroblasts from patients affected by pseudoxanthoma elasticum exhibit an altered PPi metabolism and are more responsive to pro-calcifying stimuli. J Dermatol Sci (2014) 74:72-80. doi:10.1016/j.jdermsci.2013.12.008

11. Jansen RS, Duijst S, Mahakena S, Sommer D, Szeri F, Varadi A, et al. ABCC6mediated ATP secretion by the liver is the main source of the mineralization inhibitor inorganic pyrophosphate in the systemic circulation-brief report.
$\mathrm{MM}$ and PS were in charge of the patient's management and participated in the data capture. JR carried out biochemical analysis. FJB performed the statistical analysis. MA participated in the genetic analysis. DH and DC carried out the vitamin K metabolites determination. FB and DQ coordinated the genetic analyses and helped to draft the manuscript. PV conceived of the study, participated in its design and coordination and drafted the manuscript. All authors read and approved the final manuscript.

\section{ACKNOWLEDGMENTS}

The authors would like to express their gratitude to the participants in the study and to the Spanish Association of Patients with PXE for their continuous support in the management and research. The study was supported by a grant of the Spanish Ministerio de Salud Pública e Igualdad, EC 90/2010. It did not play any role neither in study design nor in collection, analysis, and interpretation of data; in the writing of the report; and in the decision to submit the manuscript for publication. Authors also acknowledge the COST Action CA16115-EuroSoftCalcNet.

Arterioscler Thromb Vasc Biol (2014) 34:1985-9. doi:10.1161/atvbaha 114.304017

12. Rongioletti F, Bertamino R, Rebora A. Generalized pseudoxanthoma elasticum with deficiency of vitamin K-dependent clotting factors. J Am Acad Dermatol (1989) 21:1150-2. doi:10.1016/S0190-9622(89)70320-0

13. Theuwissen E, Smit E, Vermeer C. The role of vitamin $\mathrm{K}$ in soft-tissue calcification. Adv Nutr (2012) 3:166-73. doi:10.3945/an.111.001628

14. Berkner KL, Runge KW. The physiology of vitamin K nutriture and vitamin K-dependent protein function in atherosclerosis. J Thromb Haemost (2004) 2:2118-32. doi:10.1111/j.1538-7836.2004.00968

15. Hendig D, Zarbock R, Szliska C, Kleesiek K, Gotting C. The local calcification inhibitor matrix Gla protein in pseudoxanthoma elasticum. Clin Biochem (2008) 41:407-12. doi:10.1016/j.clinbiochem.2007.12.023

16. Li Q, Jiang Q, Schurgers L, Uitto J. Pseudoxanthoma elasticum: reduced gamma-glutamyl carboxylation of matrix gla protein in a mouse model (Abcc6-/-). Biochem Biophys Res Commun (2007) 364:208-13. doi:10.1016/j. bbrc.2007.09.122

17. Borst P, van de Wetering K, Schlingemann R. Does the absence of ABCC6 (multidrug resistance protein 6) in patients with pseudoxanthoma elasticum prevent the liver from providing sufficient vitamin $\mathrm{K}$ to the periphery? Cell Cycle (2008) 7:1575-9. doi:10.4161/cc.7.11.6005

18. Vanakker OM, Martin L, Schurgers LJ, Quaglino D, Costrop L, Vermeer C, et al. Low serum vitamin $\mathrm{K}$ in PXE results in defective carboxylation of mineralization inhibitors similar to the GGCX mutations in the PXElike syndrome. Lab Invest (2010) 90:895-905. doi:10.1038/labinvest.2010.68

19. Jiang Q, Li Q, Grand-Pierre AE, Schurgers LJ, Uitto J. Administration of vitamin $\mathrm{K}$ does not counteract the ectopic mineralization of connective tissues in Abcc6 (-/-) mice, a model for pseudoxanthoma elasticum. Cell Cycle (2011) 10:701-7. doi:10.4161/cc.10.4.14862

20. Brampton C, Yamaguchi Y, Vanakker O, Van Laer L, Chen LH, Thakore M, et al. Vitamin $\mathrm{K}$ does not prevent soft tissue mineralization in a mouse model of pseudoxanthoma elasticum. Cell Cycle (2011) 10:1810-20. doi:10.4161/ cc.10.11.15681

21. Gorgels TG, Waarsing JH, Herfs M, Versteeg D, Schoensiegel F, Sato T, et al. Vitamin $\mathrm{K}$ supplementation increases vitamin $\mathrm{K}$ tissue levels but fails to counteract ectopic calcification in a mouse model for pseudoxanthoma elasticum. J Mol Med (Berl) (2011) 89:1125-35. doi:10.1007/ s00109-011-0782-y

22. Will BH, Usui Y, Suttie JW. Comparative metabolism and requirement of vitamin K in chicks and rats. J Nutr (1992) 122:2354-60. doi:10.1093/jn/ 122.12 .2354 
23. Geleijnse JM, Vermeer C, Grobbee DE, Schurgers LJ, Knapen MH, van der Meer IM, et al. Dietary intake of menaquinone is associated with a reduced risk of coronary heart disease: the Rotterdam Study. J Nutr (2004) 134:3100-5. doi:10.1093/jn/134.11.3100

24. Plomp AS, Toonstra J, Bergen AA, van Dijk MR, de Jong PT. Proposal for updating the pseudoxanthoma elasticum classification system and a review of the clinical findings. Am J Med Genet A (2010) 152A:1049-58. doi:10.1002/ ajmg.a.33329

25. Le Saux O, Beck K, Sachsinger C, Silvestri C, Treiber C, Goring HH, et al. A spectrum of ABCC6 mutations is responsible for pseudoxanthoma elasticum. Am J Hum Genet (2001) 69:749-64. doi:10.1086/323704

26. Gheduzzi D, Guidetti R, Anzivino C, Tarugi P, Di Leo E, Quaglino D, et al. ABCC6 mutations in Italian families affected by pseudoxanthoma elasticum (PXE). Hum Mutat (2004) 24:438-9. doi:10.1002/humu.9284

27. Shearer MJ, Newman P. Metabolism and cell biology of vitamin K. Thromb Haemost (2008) 100:530-47. doi:10.1160/TH08-03-0147

28. Kamao M, Suhara Y, Tsugawa N, Okano T. Determination of plasma vitamin $\mathrm{K}$ by high-performance liquid chromatography with fluorescence detection using vitamin $\mathrm{K}$ analogs as internal standards. J Chromatogr B Analyt Technol Biomed Life Sci (2005) 816:41-8. doi:10.1016/j.jchromb.2004.11.003

29. Harrington DJ, Booth SL, Card DJ, Shearer MJ. Excretion of the urinary $5 \mathrm{C}$ - and $7 \mathrm{C}$-aglycone metabolites of vitamin $\mathrm{K}$ by young adults responds to changes in dietary phylloquinone and dihydrophylloquinone intakes. J Nutr (2007) 137:1763-8. doi:10.1093/jn/137.7.1763

30. Harrington DJ, Soper R, Edwards C, Savidge GF, Hodges SJ, Shearer MJ. Determination of the urinary aglycone metabolites of vitamin K by HPLC with redox-mode electrochemical detection. J Lipid Res (2005) 46:1053-60. doi:10.1194/jlr.D400033-JLR200

31. Pfendner EG, Vanakker O, Terry SF, Vourthis S, McAndrew PE, McClain MR, et al. Mutation detection in the ABCC6 gene and genotype-phenotype analysis in a large international case series affected by pseudoxanthoma elasticum. J Med Genet (2007) 44:621-8. doi:10.1136/jmg.2007.051094

32. Schurgers LJ, Cranenburg EC, Vermeer C. Matrix Gla-protein: the calcification inhibitor in need of vitamin K. Thromb Haemost (2008) 100:593-603. doi:10.1160/TH08-02-0087

33. Dituri F, Buonocore G, Pietravalle A, Naddeo F, Cortesi M, Pasqualetti P, et al. PIVKA-II plasma levels as markers of subclinical vitamin $\mathrm{K}$ deficiency in term infants. J Matern Fetal Neonatal Med (2012) 25:1660-3. doi:10.3109/ 14767058.2012.657273

34. Lok AS, Sterling RK, Everhart JE, Wright EC, Hoefs JC, Di Bisceglie AM, et al. Des- $\gamma$-carboxy prothrombin and $\alpha$-fetoprotein as biomarkers for the early detection of hepatocellular carcinoma. Gastroenterology (2010) 138:493-502. doi:10.1053/j.gastro.2009.10.031

35. Bellido-Martín L, de Frutos PG. Vitamin K-dependent actions of Gas6. Vitam Horm (2008) 78:185-209. doi:10.1016/S0083-6729(07)00009-X

36. Manfioletti G, Brancolini G, Avanzi G, Schneider C. The protein encoded by a growth arrest-specific gene (Gas6) is a new member of the vitamin $\mathrm{K}$-dependent proteins related to protein $\mathrm{S}$, a negative coregulator in the blood coagulation cascade. Mol Cell Biol (1993) 13:4976-85. doi:10.1128/ MCB.13.8.4976

37. Nakano T, Higashino K, Kikuchi N, Kishino J, Nomura K, Fujita H, et al. Vascular smooth muscle cell-derived, Gla-containing growth-potentiating factor for $\mathrm{Ca}(2+)$-mobilizing growth factors. J Biol Chem (1995) 270:5702-5 doi:10.1074/jbc.270.11.5702

38. Stenhoff J, Dahlbäck B, Hafizi S. Vitamin K-dependent Gas6 activates ERK kinase and stimulates growth of cardiac fibroblasts. Biochem Biophys Res Commun (2004) 319:871-8. doi:10.1016/j.bbrc.2004.05.070

39. Kaesler N, Immendorf S, Ouyang C, Herfs M, Drummen N, Carmeliet P, et al. Gas6 protein: its role in cardiovascular calcification. BMC Nephrol (2016) 17:52. doi:10.1186/s12882-016-0265-Z

40. Tanabea K, Nagataa K, Ohashia K, Nakanob T, Aritab H, Mizunoa K. Roles of $\gamma$-carboxylation and a sex hormone-binding globulin-like domain in receptor-binding and in biological activities of Gas6. FEBS Lett (1997) 408:306-10. doi:10.1016/S0014-5793(97)00448-1

41. Brandenburg VM, Schurgers LJ, Kaesler N, Pusche K, van Gorp RH, Leftheriotis G, et al. Prevention of vasculopathy by vitamin K supplementation: can we turn fiction into fact? Atherosclerosis (2015) 240:10-6. doi:10.1016/j. atherosclerosis.2015.02.040

Conflict of Interest Statement: The authors declare that the research was conducted in the absence of any commercial or financial relationships that could be construed as a potential conflict of interest.

Copyright (c) 2018 Carrillo-Linares, García-Fernández, Morillo, Sánchez, Rioja, Barón, Ariza, Harrington, Card, Boraldi, Quaglino and Valdivielso. This is an open-access article distributed under the terms of the Creative Commons Attribution License (CC BY). The use, distribution or reproduction in other forums is permitted, provided the original author(s) and the copyright owner are credited and that the original publication in this journal is cited, in accordance with accepted academic practice. No use, distribution or reproduction is permitted which does not comply with these terms. 